\title{
Peningkatan Keterampilan Motorik Halus melalui Kegiatan Mozaik menggunakan Bahan Biji-Bijian Untuk Kelompok B di TK Al-Husna Buring Kota Malang
}

\author{
Emmalia Marta Hapsari*, I Made Seken, Wuri Astuti \\ Universitas Negeri Malang, Jl. Semarang No. 5 Malang, Jawa Timur, Indonesia \\ *Penulis korespondensi, Surel: emmamarta11@gmail.com
}

Paper received: 2-2-2021; revised: 20-2-2021; accepted: 27-2-2021

\begin{abstract}
The observations on group B2 in Al-Husna Buring Malang Kindergarten showed that children's fine motor skills had not developed optimally. Children have not been able to move their hands and eye coordination carefully. 12 and 16 children of fine motor skills have not developed well in mosaic activities with free tearing techniques. Mosaic activities using grain ingredients are expected to develop children's fine motor skills. Mosaic activities using grain materials are done by applying glue using a brush on the drawing pattern then the child is asked to squeeze using two fingers (thumb and index finger) after that, sticking the seeds according to the instructions given. When squeezing and pasting the seeds, children can coordinate their eyes and hands and be skilled at using the fingers. This study uses a class action research design (PTK). The data analysis technique used in this study is descriptive qualitative and quantitative. The study was conducted in two cycles, one cycle carried out 2 meetings. The subject of this study was the B2 group TK Al-Husna Buring. Based on the results of observations of an increase in the results of this study indicate that there was an increase in fine motor skills ranging from pre-action, cycle I to cycle II. The results of observing the fine motor skills of children in pre-action were 25 percent increased to 31.25 percent in cycle I. The fine motor skills of children increased again in the second cycle very well, reaching 81.25 percent or increasing by 50 percent from cycle I. Researchers provide advice for teachers to improve fine motor skills through various activities that attract and motivate children to develop their fine motor skills optimally.
\end{abstract}

Keywords: fine motor; mosaic; grains

\begin{abstract}
Abstrak
Hasil pengamatan pada kelompok B2 di TK Al-Husna Buring Malang menunjukkan bahwa keterampilan motorik halus anak belum berkembang dengan optimal. Anak belum mampu menggerakkan tangan dan koordinasi mata dengan cermat. 12 dan 16 anak keterampilan motorik halusnya belum berkembang dengan baik pada kegiatan mozaik dengan teknik merobek bebas. Kegiatan mozaik menggunakan bahan biji-bijian diharapkan dapat mengembangkan keterampilan motorik halus anak. Kegiatan mozaik menggunakan bahan biji-bijian dilakukan dengan mengoles lem menggunakan kuas pada pola gambar kemudian anak diminta untuk menjimpit menggunakan dua jari (ibu jari dan jari telunjuk) setelah itu, menempelkan biji-bijian sesuai instruksi yang diberikan. Pada saat menjimpit dan menempelkan biji-bijian anak dapat mengkoordinasi mata dan tangan serta terampil menggunakan jari-jari. Penelitian ini menggunakan rancangan penelitian tindakan kelas (PTK). Teknik analisis data yang digunakan pada penelitian ini adalah deskriptif kualitatif dan kuantitatif. Penelitian dilakukan sebanyak dua siklus, satu siklus dilaksanakan 2 pertemuan. Subjek penelitian ini adalah anak kelompok B2 TK Al-Husna Buring. Berdasarkan hasil pengamatan terjadi peningkatan Hasil dari penelitian ini menunjukkan bahwa terjadi peningkatan keterampilan motorik halus mulai dari pra tindakan, siklus I sampai siklus II. Hasil pengamatan keterampilan motorik halus anak pada pra tindakan adalah 25 persen meningkat menjadi 31,25 persen pada siklus I. Keterampilan motorik halus anak kembali meningkat pada siklus II dengan sangat baik yaitu mencapai 81,25 persen atau meningkat sebanyak 50 persen dari siklus I. Peneliti memberikan saran bagi guru untuk meningkatkan motorik halus melalui berbagai kegiatan yang menarik dan memotivasi anak dalam mengembangkan keterampilan motorik halusnya secara optimal.
\end{abstract}


Kata kunci: motorik halus; mozaik; biji-bijian

\section{Pendahuluan}

Masa usia dini merupakan pondasi awal bagi pertumbuhan dan perkembangan selanjutnya. Pertumbuhan dan perkembangan anak agar tercapai secara optimal, maka dibutuhkan situasi dan kondisi yang kondusif untuk menstimulasi tumbuh kembang anak. Perkembangan anak sangat terlihat salah satunya yaitu perkembangan fisik motorik. Perkembangan motorik pada usia dini merupakan suatu hal yang sangat penting bagi perkembangan anak. Anak yang memiliki keterampilan motorik baik akan mudah mempelajari hal-hal baru yang sangat bermanfaat dalam menjalani pendidikan. Penguasaan keterampilan motorik dapat memacu anak untuk menekuni bidang tertentu sejak dini seperti membuat kerajinan, melukis, bermain musik dan sebagainya. Perkembangan fisik motorik terdiri atas 2 jenis, yaitu motorik kasar dan motorik halus. Kegiatan motorik kasar merupakan gerakan yang berhubungan dengan otot-otot besar, seperti berjalan, berlari, melompat dan sebagainya. Kegiatan motorik halus merupakan gerakan yang berhubungan dengan otot-otot kecil serta memerlukan koordinasi mata dan tangan, seperti menulis, mewarnai, menganyam, menempel dan sebagainya.

Keterampilan motorik halus menjadi salah satu keterampilan yang dikembangkan di TK, terutama di dalam kelas. Kegiatan yang berhubungan dengan keterampilan motorik halus berperan dalam kehidupan sehari-hari. Menurut Sumantri (2005) motorik halus adalah penggunaan otot-otot kecil seperti jari-jemari dan tangan yang sering memerlukan kecermatan dan koordinasi mata dan tangan untuk mencapai pelaksanaan keterampilan yang berhasil. Senada dengan pendapat Susanto (2015) motorik halus adalah gerakan yang hanya melibatkan bagian-bagian tubuh tertentu dan dilakukan otot-otot kecil saja, karena tidak memerlukan tenaga namun memerlukan koordinasi yang cermat. Dapat disimpulkan bahwa motorik halus merupakan gerakan yang hanya melibatkan otot-otot kecil. Gerakan ini tidak memerlukan tenaga melainkan membutuhkan koordinasi mata dan tangan yang cermat.

Semakin baik gerakan motorik halus membuat anak dapat berkreasi, seperti menggunting kertas dengan hasil guntingan yang lurus, menggambar sederhana lalu diberi warna, menganyam kertas dan menajamkan pensil dengan rautan. Menurut Permendikbud No. 137 Tahun 2014 tentang Standar Nasional Pendidikan Anak Usia Dini, tingkat pencapaian perkembangan motorik halus anak usia 5-6 tahun yaitu (1) menggambar sesuai gagasannya, (2) meniru bentuk, (3) melakukan eksplorasi dengan berbagai media dan kegiatan, (4) menggunakan alat tulis dan alat makan, (5) menggunting sesuai dengan pola, (6) menempel gambar dengan tepat, (7) mengekspresikan diri melalui gerakan menggambar secara rinci.

Berdasarkan pengamatan di kelompok B2 TK Al-Husna Jl. KH. Malik Dalam, Buring, Kecamatan Kedungkandang, Kota Malang menunjukkan bahwa keterampilan motorik halus anak belum berkembang dengan baik. Kurangnya pengembangan keterampilan motorik halus terlihat dari anak belum mampu menggerakkan tangan dan koordinasi matanya dengan tepat. Pada kegiatan mozaik menyobek kertas lipat lalu menempel pada pola gambar banyak anak yang mengalami kesulitan. Hasil sobekan anak cenderung besar, seharusnya anak pada kegiatan tersebut menyobek kertas dengan ukuran yang kecil. Hasil pengamatan yang dilakukan terdapat 12 dari 16 anak yang kemampuan motorik halusnya belum berkembang dengan baik. 
Solusi untuk mengatasi permasalahan perkembangan motorik halus dapat dilakukan dengan melakukan kegiatan mozaik menggunakan bahan biji-bijian untuk meningkatkan keterampilan motorik halus. Biji-bijian merupakan bakal biji yang berasal dari tumbuhan yang telah masak. Bahan biji-bijian yang akan digunakan untuk kegiatan mozaik dalam penelitian ini yaitu beras jagung, ketan hitam dan beras merah. Biji-bijian yang digunakan berasal dari jenis yang sama yaitu serelia. Serelia merupakan biji-bijian yang ditanam untuk di panen bijinya sebagai sumber karbohidrat atau pati, seperti: beras, jagung, gandum dan sebagainya. Peneliti menggunakan bahan biji-bijian tersebut dimaksudkan agar menarik bagi anak karena bahan tersebut belum pernah digunakan di sekolah. Pemanfaatan biji-bijian dilakukan karena tersedia di alam, sehingga dapat digunakan sebagai alternatif bagi kegiatan anak.

Kegiatan mozaik pada anak TK merupakan kemampuan berolah seni rupa yang diwujudkan dengan keterampilan merekatkan bahan-bahan alam atau buatan berukuran kecil sampai menutup pola gambar di bidang dasar yang digunakan. Mozaik dipilih karena kegiatan ini dapat melatih koordinasi jari tangan dan mata. Menurut Muharrar (2013) Mozaik merupakan suatu gambar atau pola tertentu yang dibuat dengan cara menempelkan bahan atau unsur kecil sejenis (baik bahan, bentuk, maupun ukurannya) yang disusun berdempetan pada sebuah bidang. Mozaik menggunakan potongan-potongan kecil yang digunakan untuk membuat pola atau gambar. Menurut Dewi dkk (2014) mozaik merupakan sebuah karya seni lukis yang dalam pembuatannya menggunakan kepingan atau potongan benda-benda yang direkatkan dengan lem dan disusun sedemikian rupa pada bidang datar sehingga membentuk suatu desain. Dapat disimpulkan bahwa mozaik merupakan suatu karya seni yang dilakukan dengan cara menempelkan atau merekatkan bahan-bahan yang memiliki ukuran kecil. Bahanbahan yang digunakan dapat berupa kepingan, potongan kertas maupun biji-bijian yang memiliki ukuran kecil sejenis.

Menurut Sumanto (2005) langkah kerja dalam kegiatan mozaik yaitu: mempersiapkan bahan, alat, bahan pembantu dan bidang dasaran atau benda yang akan dihias. Pelaksanaan kerja meliputi: (1) membuat rencana gambar di atas bidang dasaran, (2) menempelkan bahan yang akan digunakan untuk kegiatan mozaik di atas rencana gambar sampai menutup dengan rapat keseluruhan rencana gambar, dan (3) penyelesaian yaitu dengan merapikan bagianbagian hasil mozaik.

Kegiatan menempel sering digunakan dalam kegiatan pembelajaran pada kelompok B2. Pada saat pembelajaran motorik halus melalui kegiatan menempel menggunakan kertas terdapat anak yang belum mampu melakukan dengan tepat. Menempel dengan tepat adalah kegiatan menempel yang dilakukan dengan menutup seluruh bagian pola gambar. Menempel yang tepat dalam kegiatan ini yaitu menempel biji-bijian pada pola gambar dengan penuh dan sesuai aturan. Kegiatan menempel menggunakan biji-bijian pernah diterapkan namun dilakukan sebagai pekerjaan rumah sehingga kegiatan menempel menggunakan bahan alam tidak dilakukan sendiri oleh anak di sekolah. Bahan biji-bijian yang digunakan kurang bervariasi karena hanya menggunakan biji jagung dan kacang hijau.

Tujuan penelitian yang dilakukan adalah untuk meningkatkan keterampilan motorik halus anak melalui kegiatan mozaik menggunakan bahan biji-bijian. Dengan dilakukannya penelitian ini diharapkan dapat memperbaiki pembelajaran yang telah ada dan bermanfaat bagi pihak yang bersangkutan. 


\section{Metode}

Penelitian ini menggunakan rancangan Penelitian Tindakan Kelas (PTK). Ciri utama PTK yaitu: masalah berasal dari latar atau kelas tempat penelitian dilakukan, proses pemecahan masalah dilakukan secara bersiklus, tujuannya untuk memecahkan masalah pembelajaran di kelas atau meningkatkan kualitas pembelajaran di kelas. Pemilihan penelitian ini dianggap tepat oleh peneliti karena sesuai dengan masalah yang diangkat, yaitu permasalahan keterampilan motorik halus terhadap peserta didik yang muncul pada suatu kelas di kelompok B2 TK Al-Husna Buring. Model penelitian tindakan kelas yang digunakan yaitu kolaboratif. PTK model kolaboratif yaitu bentuk kerjasama antara peneliti dengan guru kelas sebagai pelaksana tindakan.

Penelitian ini menggunakan model penelitian tindakan kelas yang dikembangkan oleh Arikunto (2014). Arikunto mengembangkan model siklus yang dikembangkan oleh Kurt. Model penelitian yang dikembangkan oleh Arikunto dipilih karena setiap siklus dilakukan secara empat tahap, terdiri dari: planning (menyusun rancangan tindakan), acting (pelaksanaan tindakan), observing (pengamatan), reflecting (refleksi).

Penelitian ini dilaksanakan di TK Al-Husna Jl. KH. Malik Dalam, Buring, Kecamatan Kedungkandang, Kota Malang. Subjek penelitian ini adalah anak kelompok B2 di TK Al-Husna Buring dengan jumlah 16 anak terdiri dari 6 anak laki-laki dan 10 anak perempuan. Teknik analisis data yang digunakan dalam penelitian ini adalah deskriptif kualitatif dan kuantitatif. Instrumen yang digunakan dalam penelitian ini meliputi: lembar observasi aktivitas guru, lembar observasi aktivitas anak, lembar pengumpulan data kemampuan motorik halus, catatan lapangan dan dokumentasi berupa foto selama kegiatan berlangsung, hasil karya dan RPPH.

Penelitian yang dilakukan peneliti dilaksanakan dua siklus, setiap siklus dilaksanakan dua kali pertemuan. Pada siklus I dilakukan dengan adanya perencanaan kegiatan yang akan dilakukan. Kegiatan yang telah direncanakan kemudian dilakukan tindakan dan pengamatan dengan melakukan observasi menggunakan lembar penilaian keterampilan motorik halus. Kegiatan yang telah dilaksanakan setelah itu dilakukan refleksi untuk mengetahui letak keberhasilan dan hambatan dari tindakan yang telah dilaksanakan pada siklus I, kemudian menentukan rancangan untuk siklus II. Kegiatan siklus II ditujukan untuk meyakinkan atau menguatkan hasil. Kegiatan pada siklus II memiliki berbagai tambahan perbaikan dari tindakan sebelumnya untuk memperbaiki berbagai hambatan atau kesulitan yang ditemukan pada siklus I.

Peningkatan keterampilan motorik halus melalui kegiatan mozaik menggunakan bahan biji-bijian, terdapat indikator pada lembar penilaian yaitu: (1) Anak mampu menjimpit bijibijian, (2) Anak mampu memberi lem pada pola di kertas menggunakan kuas, (3) Anak mampu menempelkan biji-bijian di pola sesuai aturan. Hasil analisis data akan dijadikan dasar untuk menentukan keberhasilan pemberian tindakan dan acuan untuk melaksanakan tindakan selanjutnya apabila tindakan sebelumnya tidak berhasil atau tidak mencapai $\geq 75 \%$ dari kriteria ketercapaian kelas.

\section{Hasil dan Pembahasan}

Pelaksanaan kegiatan yang telah dilaksanakan pada siklus I anak-anak merasa senang dan tertarik dengan adanya biji-bijian yang belum pernah digunakan. Anak-anak sangat antusias saat guru menunjukkan contoh karya mozaik yang telah jadi sebelum kegiatan mozaik dimulai, hasil tindakan menunjukkan bahwa keterampilan motorik halus anak masih perlu 
ditingkatkan. Pengelolaan kelas cukup terkontrol pada pertemuan 2 sehingga suasana kelas menjadi kondusif dalam pelaksanaan pembelajaran untuk meningkatkan keterampilan motorik halus anak di TK Al-Husna Buring, Malang. Pada pelaksanaan kegiatan pembelajaran hasil yang diamati oleh peneliti saat siklus I pertemuan 1 dan 2 diperoleh hasil sebagai berikut:

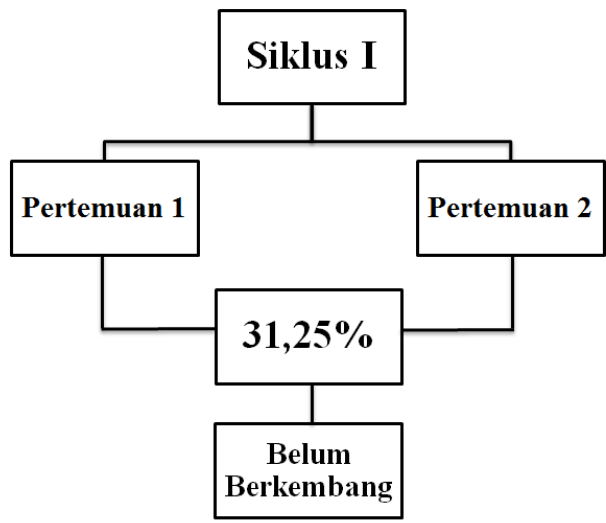

Gambar 1. Hasil Akumulasi Siklus I Keterampilan Motorik Halus Anak Kelompok B2 TK AlHusna Buring

Hasil dari akumulasi siklus I pertemuan 1 dan 2 ketercapaian kelas belum mencapai kriteria ketercapaian. Hasil yang belum memenuhi kriteria ketercapaian karena pengkondisian kelas yang kurang dan anak tidak memperhatikan instruksi dari guru. Perlu adanya perbaikan pada siklus II untuk meningkatkan keterampilan motorik halus anak agar tercapai secara optimal. Hasil penilaian keterampilan motorik halus anak pada siklus I pertemuan 1 dan 2 jumlah ketercapaian sebanyak 31,25\%. Hasil yang didapat dari akumulasi siklus I pertemuan 1 dan pertemuan 2 diketahui bahwa 5 anak mendapatkan kriteria ketercapaian berkembang sesuai harapan (BSH), 10 anak mendapatkan ketercapaian mulai berkembang (MB) dan 1 anak mendapatkan ketercapaian belum berkembang (BB). Pada siklus I saat menjimpit biji-bijian anak-anak masih menggenggam lalu menaburkannya pada bidang dasar yang telah dilapisi oleh lem. Saat mengoles lem pada pola gambar menggunakan kuas, anak-anak mengoles sampai keluar dari garis pola. Saat menempelkan biji-biji pada pola anak-anak sudah sesuai dengan instruksi, namun biji yang ditempelkan kurang penuh, sehingga hasil yang didapat kurang optimal.

Peneliti melaksanakan wawancara dengan guru kelompok B2 setelah kegiatan pembelajaran siklus I pertemuan 2 berakhir. Hasil wawancara dengan guru kelompok B2 mengenai penerapan kegiatan mozaik pada siklus I pertemuan 1 dan 2, guru memberikan pernyataan bahwa kegiatan mozaik ini dapat meningkatkan keterampilan motorik halus anak, anak dapat mencoba langsung menempelkan biji-bijian yang belum pernah digunakan, anak dapat telaten dan sabar dalam menempelkan biji-bijian. Kegiatan motorik halus sangat menarik bagi anak, hal ini dapat dilihat dari antusias anak-anak dalam pelaksanaan kegiatan mozaik menggunakan bahan biji-bijian. Pelaksanaan kegiatan pembelajaran sudah cukup baik, tetapi masih perlu dilakukan perbaikan pada siklus II. Perbaikan yang dapat dilakukan seperti guru lebih menjelaskan langkah-langkah kegiatan dengan detail hingga seluruh anak paham dan mampu mengikuti sesuai instruksi yang diberikan. Guru juga dapat mengkondisikan kelas agar anak-anak mendengarkan yang dijelaskan oleh guru dengan terus memotivasi anak. 
Kegiatan mozaik yang dilakukan kembali pada siklus II diharapkan dapat memperbaiki kekurangan pada siklus I. Kegiatan mozaik pada siklus II inovasi yang diberikan adalah pada desain pola gambar dibuat lebih timbul agar lebih menarik minat anak dan saat memberikan lem tidak akan keluar dari garis. Berdasarkan pelaksanaan kegiatan yang telah dilaksanakan pada siklus II anak-anak mulai stabil sehingga kondisi kelas sudah terkontrol dengan cukup baik. Anak-anak mengikuti apa yang di instruksikan oleh guru. Anak-anak terlihat tertarik dan antusias saat guru menunjukkan contoh karya mozaik yang telah jadi sebelum kegiatan mozaik dimulai. Pada siklus II guru menjelaskan secara berulang hingga anak benar-benar paham. Pada pertemuan 2 hampir seluruh anak mengikuti instruksi dari guru dan menjimpit biji-bijian dengan sangat baik. Anak-anak menempelkan biji-bijian dengan tepat sesuai instruksi yang diberikan oleh guru. Hasil yang diperoleh dari siklus II diketahui bahwa proses kegiatan mozaik untuk meningkatkan keterampilan motorik halus menunjukkan hasil yang maksimal dan mencapai kriteria ketercapaian sesuai harapan. Pada pelaksanaan kegiatan pembelajaran hasil yang diamati oleh peneliti saat siklus II pertemuan 1 dan 2 diperoleh hasil sebagai berikut:

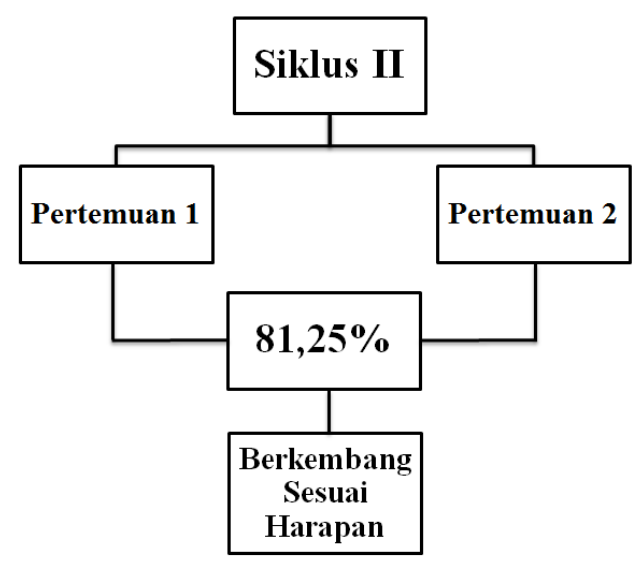

Gambar 2. Hasil Akumulasi Siklus II Keterampilan Motorik Halus Anak Kelompok B2 TK AlHusna Buring

Hasil dari akumulasi siklus II pertemuan 1 dan 2 ketercapaian kelas sudah mencapai kriteria ketercapaian berkembang sesuai harapan. Pada siklus I hasil yang diperoleh adalah $31,25 \%$ dan pada siklus II hasil yang diperoleh adalah $81,25 \%$ sehingga dari siklus I ke siklus II meningkat sebanyak 50\%. Hasil yang didapat dari akumulasi siklus II pertemuan 1 dan 2 diketahui bahwa 10 anak mendapatkan kriteria ketercapaian berkembang sangat baik (BSB), 3 anak mendapatkan ketercapaian berkembang sesuai harapan (BSH) dan 3 anak mendapatkan ketercapaian mulai berkembang (MB). Pada siklus II anak-anak sudah menjimpit biji-bijian menggunakan dua jari dengan baik. Saat mengoles lem menggunakan kuas anakanak sudah mengoles dengan cukup banyak dan tidak keluar garis pola. Saat menempelkan biji-bijian ke pola gambar sudah sesuai dengan instruksi yang diberikan dan cukup memenuhi pola gambar. Dari hasil penelitian yang telah dilakukan dapat ditarik kesimpulan bahwa kegiatan mozaik dapat meningkatkan keterampilan motorik halus anak secara optimal. Penerapan kegiatan mozaik menggunakan bahan biji-bijian dapat meningkatkan keterampilan motorik halus anak kelompok B2 TK Al-Husna Buring, Malang.

Peneliti melaksanakan wawancara dengan guru kelompok B2 dilakukan setelah kegiatan pembelajaran siklus II pertemuan 2 berakhir. Hasil wawancara dengan guru 
kelompok B2 mengenai penerapan kegiatan mozaik pada siklus II pertemuan 1 dan 2, guru memberikan pernyataan bahwa kegiatan mozaik ini dapat meningkatkan keterampilan motorik halus anak. Pada siklus II anak lebih tertarik dengan desain pola gambar yang dibuat menonjol beberapa bagiannya. Anak telaten dan sabar dalam menjimpit dan menempelkan biji-bijian. Anak-anak menunjukkan peningkatan yang cukup bagus, lebih mendengarkan instruksi yang diberikan dan sudah lebih berkembang keterampilan motorik halus terutama dalam kegiatan mozaik. Pada pelaksanaan kegiatan mozaik mulai dari pra tindakan, siklus I dan siklus diperoleh hasil sebagai berikut:

Tabel 1. Hasil Penilaian Keterampilan Motorik Halus Kelompok B2 TK Al-Husna Buring

\begin{tabular}{lcc}
\hline Pelaksanaan & Persentase & Ketercapaian \\
\hline Pra Tindakan & $25 \%$ & Belum Berkembang \\
Siklus I & $31,25 \%$ & Belum Berkembang \\
Siklus II & $81,25 \%$ & Berkembang Sesuai Harapan \\
\hline
\end{tabular}

Berdasarkan pengamatan yang dilakukan pelaksanaan penerapan kegiatan mozaik untuk meningkatkan keterampilan motorik halus anak sudah meningkat dari siklus I ke siklus II. Kegiatan yang telah dilaksanakan pada siklus II anak-anak sudah mampu menjimpit bijibijian menggunakan dua jari dengan sangat baik. Anak-anak mulai mampu mengkoordinasi mata dan tangan dalam menempelkan biji-bijian sesuai instruksi yang diberikan dengan cara menjimpit. Ketiga indikator yang diteliti menunjukkan hasil peningkatan yang baik. Hasil temuan dari siklus I ke siklus II sudah mengalami peningkatan yang signifikan. Pada siklus II Hasil yang di dapat di siklus II yaitu sebanyak $81,25 \%$, hal ini telah melebihi kriteria ketercapaian yang ditetapkan yaitu $75 \%$, sehingga penelitian ini dihentikan di siklus 2 . Hasil yang ditemukan bahwa selama kegiatan mozaik berlangsung anak-anak merasa senang dengan adanya biji-bijian yang bervariasi dan desain pola yang unik.

\subsection{Penerapan Kegiatan Mozaik Menggunakan Bahan Biji-Bijian untuk Meningkatkan Motorik Halus Anak di TK Al-Husna Buring}

Kegiatan mozaik merupakan salah satu kegiatan yang dipilih peneliti sebagai upaya dalam meningkatkan keterampilan motorik halus anak. Penerapan kegiatan mozaik dapat menstimulus otot kecil anak dalam melatih koordinasi mata dan tangan serta keterampilan jari-jari. Sumantri (2005:143) menyatakan bahwa motorik halus adalah penggunaan otot-otot kecil seperti jari-jemari dan tangan yang sering memerlukan kecermatan dan koordinasi mata dan tangan untuk mencapai pelaksanaan keterampilan yang berhasil. Pada penerapannya kegiatan mozaik dapat melatih anak untuk mengoles lem menggunakan kuas, menjimpit bijibijian dan menempelkan biji-bijian sesuai arahan yang telah ditentukan. Penelitian ini membuktikan bahwa melalui kegiatan mozaik keterampilan motorik halus anak mengalami peningkatan.

Pelaksanaan kegiatan mozaik di TK Al-Husna Buring dilaksanakan secara kelompok, setiap kelompok terdiri dari 5-6 anak. Guru telah melaksanakan langkah-langkah kegiatan yang diungkapkan oleh Sumanto (2005:89) meliputi guru menyiapkan pola gambar di kertas sesuai ukuran yang di ingikan, menyiapkan alat dan bahan yang diperlukan, guru mendemonstrasikan langkah kerja membuat mozaik mulai dari mengoles lem hingga menempelkan bahan pada pola gambar yang disediakan. Pada saat pelaksanaan kegiatan, guru 
menunjukkan contoh karya mozaik yang telah jadi sebagai penunjang dengan tema kegiatan pada waktu penelitian. Menunjukkan contoh karya yang telah jadi bertujuan untuk membuat anak lebih tertarik pada kegiatan mozaik yang berdampak pada munculnya semangat anak untuk belajar.

Pelaksanaan siklus I anak-anak terlihat kesulitan dalam kegiatan mozaik. Hal ini karena masih banyak anak-anak yang belum memahami perintah yang didemontrasikan oleh guru. Pada pelaksanaan di siklus I pertemuan 1 hampir keseluruhan anak tidak menjimpit biji-bijian melainkan menggenggam, pada pertemuan 2 terdapat 1 anak yang mulai mampu menjimpit biji-bijian menggunakan dua jari. Pada pelaksanaan di siklus II pertemuan 1 anak-anak mulai dapat terkondisi dengan cukup baik sehingga 9 anak mulai mampu menjimpit dengan baik, hal ini semakin meningkat dengan baik pada pertemuan 2 yakni sebanyak 14 anak mampu menjimpit menggunakan dua jari dengan sangat baik.

\subsection{Peningkatan Keterampilan Motorik Halus Anak melalui Kegiatan Mozaik Menggunakan Bahan Biji-Bijian}

Kegiatan mozaik dapat meningkatkan motorik halus anak karena melalui kegiatan ini anak dilatih untuk menggerakan otot tangan dan koordinasi mata yang tepat. Kegiatan mozaik disenangi oleh anak-anak karena bahan yang digunakan adalah biji-bijian yang memiliki warna alami dan belum pernah digunakan dalam kegiatan di sekolah. Bahan biji-bijian yang digunakan sependapat dengan Muharrar (2013:72) bahwa mozaik dapat dihasilkan dari berbagai macam material, meliputi bahan-bahan alam maupun sintesis. Bahan yang digunakan untuk membuat mozaik antara lain: kertas warna, biji-bijian, kulit, mika, karet, batu-batuan, kaca, logam, keramik dan porselen.Biji-bijian yang digunakan yaitu beras jagung, beras merah dan kertan hitam. Pelaksanaan pembelajaran kegiatan mozaik diawali pada pratindakan. Kegiatan mozaik pada pratindakan menggunakan kertas lipat yang disobek menjadi ukuran kecil terdapat 11 dari 15 anak mengalami kesulitan. Pada awal semester 2 terdapat 1 anak pindahan sehingga jumlah kelompok B2 bertambah menjadi 16 anak.

Ketercapaian pada pra tindakan sebesar 25\% meningkat menjadi 31,25\% pada siklus I. Hal ini disebabkan pada siklus I beberapa anak mengalami kesulitan karena tidak memperhatikan saat guru mendemonstrasikan langkah-langkah kegiatan mozaik. Sebagai perbaikan pada siklus I guru melaksanakan tindakan perbaikan pada siklus II. Siklus II terlihat bahwa anak-anak semakin paham dan mampu melaksanakan kegiatan mozaik menggunakan bahan biji-bijian sesuai langkah-langkah dan instruksi yang diberikan guru. Peningkatan ketercapaian anak pada siklus I ke siklus II sebanyak 50\%. Siklus I hasil yang didapat sebanyak $31,25 \%$ dan meningkat pada siklus II menjadi $81,25 \%$, hal ini sudah melebihi tingkat ketercapaian yang ditetapkan yaitu $75 \%$.

Berdasarkan penjelasan yang telah dipaparkan, maka dapat disimpulkan bahwa dengan kegiatan mozaik menggunakan bahan biji-bijian dapat meningkatkan keterampilan motorik halus anak usia dini. Hal ini sesuai dengan Permendikbud No. 137 Tahun 2014 tentang Standar Nasional Pendidikan Anak Usia Dini tentang tingkat pencapaian motorik halus anak usia 5-6 tahun yaitu: (1) menggambar sesuai gagasannya, (2) meniru bentuk, (3) melakukan eksplorasi dengan berbagai media dan kegiatan, (4) menggunakan alat tulis dan alat makan dengan benar, (5) menggunting sesuai dengan pola, (6) menempel gambar dengan tepat, (6) menempel gambar dengan tepat dan (7) mengekspresikan diri melalui gerakan menggambar secara rinci. 
Kegiatan mozaik yang dipilih peneliti sebagai upaya dalam meningkatkan keterampilan motorik halus anak dalam melatih koordinasi mata dan tangan serta jari-jari pada kelompok B2 TK Al-Husna Buring.Pembahasan difokuskan pada mengaitkan data dan hasil analisisnya dengan permasalahan atau tujuan penelitian dan konteks teoretis yang lebih luas. Dapat juga pembahasan merupakan jawaban pertanyaan mengapa ditemukan fakta seperti pada data. Pembahasan ditulis melekat dengan data yang dibahas. Pembahasan diusahakan tidak terpisah dengan data yang dibahas.

\section{Simpulan}

Berdasarkan hasil penellitain tindakan kelas yang dilaksanakan dapat disimpulkan kegiatan mozaik menggunakan bahan biji-bijian dapat meningkatkan keterampilan motorik halus anak kelompok B2 TK Al-Husna Buring, dengan langkah-langkah pembelajaran sebagai berikut: (a) guru menyiapkan alat dan bahan untuk kegiatan mozaik anak, (b) guru menjelaskan tema pada hari itu, (c) guru menunjukkan contoh mozaik yang sudah jadi kemudian mendemonstrasikan langkah-langkah kegiatan mozaik pada anak, (d) anak mengoles lem di pola menggunakan kuas, menjimpit biji-bijian menggunakan dua jari yaitu ibu jari dan jari telunjuk kemudian menempelkan pada pola gambar sesuai instruksi yang diberikan, (e) hasil karya anak diberi penghargaan berupa bintang.

Melalui kegiatan mozaik menggunakan bahan biji-bijian terbukti dapat meningkatkan keterampilan motorik halus anak meliputi koordinasi mata dan tangan serta keterampilan jarijari. Anak-anak terlihat antusias saat melaksanakan kegiatan mozaik dengan bahan dan desain pola gambar di bidang tempel yang digunakan. Anak-anak sudah mampu menjimpit menggunakan dua jari dengan sangat baik pada siklus II. Hasil peningkatan siklus I ke siklus II yaitu 50\%. Pada siklus I keterampilan motorik halus anak mencapai $31,25 \%$ dan pada siklus II meningkat menjadi $81,25 \%$.

Hasil penelitian ini dapat memberikan masukan bagi guru dapat menerapkan kegiatan mozaik secara berulang-ulang untuk meningkatkan keterampilan motorik halus anak. Dalam pelaksanaan kegiatan mozaik sebaiknya guru memberi instruksi hingga anak benar-benar paham dan dapat menyelesaikan kegiatan dengan hasil yang baik. Guru diharapkan dapat menggunakan berbagai macam bahan, salah satu bahan yang mudah didapatkan dan dekat dengan anak yaitu biji-bijian. Biji-bijian yang digunakan sebaiknya bervariasi dan memiliki warna alami agar anak lebih tertarik dengan suatu hal yang baru. Sarana dan prasarana lebih ditingkatkan demi kelancaran kegiatan yang berhubungan dengan motorik halus.

Bagi peneliti selanjutnya diharapkan dapat mencoba penelitian dengan menggunakan media atau bahan lain yang lebih inovatif dalam kegiatan untuk mengembangkan aspek perkembangan anak seperti kognitif, bahasa, atau seni demi pemahaman yang lebih baik dalam penerapannya. Peneliti selanjutnya diharapkan dapat mengembangkan kegiatan yang berhubungan dengan motorik halus.

\section{Daftar Rujukan}

Arikunto, S. (2014). Penelitian Tindakan Kelas. Jakarta: Bumi Aksara.

Dewi, N. W. R. (2014). Penerapan Teknik Mozaik Berbantuan Media Bahan Alam untuk Meningkatkan Kreativitas Melukis Anak. Jurnal PG-PAUD Universitas Pendidikan Ganesha. 2(1).

Muharrar, S., \& Verayanti, S. (2013). Kreasi Kolase, Montase, Mozaik Sederhana. Jakarta: Erlangga.

Peraturan Menteri Pendidikan Nasional Nomor 137 Tahun 2014 tentang Standar Nasional Pendidikan Anak Usia Dini. (2014). Jakarta: Menteri Pendidikan dan Kebudayaan Republik Indonesia. 
Jurnal Pembelajaran, Bimbingan, dan Pengelolaan Pendidikan, 1(2), 2021, 91-100

Sumanto. (2005). Pengembangan Kreativitas Seni Rupa Anak TK. Jakarta: Depdiknas.

Sumantri. (2005). Model Pengembangan Keterampilan Motorik Anak Usia Dini. Jakarta: Depdiknas.

Susanto, A. (2015). Bimbingan dan Konseling di Taman Kanak-Kanak. Jakarta: Prenadamedia Group. 